\title{
The Impact of the Inclusion Method (Embedding Multi-Levels) on Learning Some Motor Skills and Some Psychological Variables in the Category of Sight Impaired Pupils
}

\author{
Gehan Mohamed El-Lithy El-Malah*
}

\begin{abstract}
:
This study aims at using The Inclusion method (embedding multi-levels) on learning some Motor skills and some psychological variables in the category of sight impaired pupils. The researcher used the experimental methodology and choose one of its design pre and post measurement for two groups one experimental and the other control, The sample has been selected of students in of visually impaired students The researcher selected sample in the manner the process of the students of middle prep school (grade I and II) The volume of the sample (19) students, and were divided into(7) students of the experimental group, (7) students of the control group, and reached the group reconnaissance (5) students, for the academic year 2010, this research aims to identify the impact of the use of self-learning method of multi-level (inclusion) on the visually impaired pupils in Learn some motor skills in athletics (running, jumping, throwing), Learn some motor skills in basketball (shooting, chest pass, and scroll over the head),Satisfaction of motion And the level of ambition.The result of the study the experimental group superiority than the control groups after using the method to include all the variables in the research.
\end{abstract}

Keywords: embedding method - sight impair- the inclusion

\section{Introduction:}

$\mathrm{E}$ ducation should not discriminate between normal and non-students normal, a disabled individual has the right to the care covered by the education and care to feel satisfied his life and be balanced with his normal peers, including offers of its educational services and a visual disability play an important role in the educational process, It is the direct source and accurately for the growth of knowledge and underlying the work of the rest of the senses, and a lot of studies show that the visual impaired suffer from sense of inferiority and dissatisfaction to feelings of helplessness and feelings of fear and mistrust, many miss out of motor skills. We should interest them in things that help them to be responsibility and exit from disability, the weak vision enable to do all what

* Curriculum and Teaching Methods Dept., Faculty of Physical Education, Helwan University, Egypt. the normal person do through the use of that remains of his sight.Therefore the education program of visually impaired must aim to benefit from the remainder of the sense of sight with to reduce the pressure of a sense of disability and the development of selfconfidence and providing them with knowledge and expertise and the development of independence and out of the isolation and complacency and try to reach the level of their peers at private education schools on the use of special means suit the degree of disability. (1), (2)

Both of Gaber Abdel-Hamid (2006), and Ali Rashid (2005) see that the use of modern methods in teaching helps raising students' motivation in learning, and that the recent trend in the educational process reason to be positive active learner in obtaining experience which leads to raise the level of performance to the highest level of their abilities allowed. (3), (4) 


\section{Research problem and its importance:}

The visual disability imposed on the child's restrictions on his mobility so he becomes afraid of the practice of motor activity and therefore especially programs kinetics must be set up contribute to the development of selfconfidence, independence, extract his pent-up energy and development the concentration and synergy motor. Most of the studies show that the approach of visually impaired is no different to their studies on sighted only in the methods of teaching and educational means which used to acquire the educational experience, based on the remains of the visual help of some means, such as special books on related large words and images and clear details, and the best paintings which clearly defined and could be suspended on the walls and write in font size more (24) spaced between the lines so as not to strain the eye and write a different color on the color of dark paper. And these means are used within their classrooms and to help them to cope with their normal peers. (5), (6), (7)

The method of multi-levels of the best methods that take into account individual differences depends on where the integration of a range of multi-level students with each other within the lesson, but take into account that every child is progressing as personal abilities to increase the chances of success and equal opportunities. (3)

Joyce M. Harrison explains the difference between this method and other methods is that the learner chooses the level of difficulty according to his abilities, which increases the chances of success and move to the next level to achieve the final goal, and the inclusion of all pupils depends on the activity in spite of the multiplicity of individual differences among them and help to assess the student to himself and to identify potential self without fear or worried.(8)

The students take the decision of work by himself and the performance itself, which helped him to stand on its own, independence, and create a state of satisfaction and providing opportunities for success and increased concentration, which helps to progress in level and is the technique of the methods that help to learn motor skills and self-learning and self- confidence and increase the level of ambition. The method differs from the rest of embedding methods as it gives the learner the opportunity to take a decision on it. (4)

I have noted the researcher through thesupervision of the students practical education in the schools of special groups do not use methods faculty in modern teaching these classes, and teachers use the traditional methods only, which lead to negative student during learning and not taking into account the differences between the students despite the fact that the principle of individual differences in learning special categories of themostimportant principles of education.

Visually impaired students of a class suffer from default in the performance level of skills different kinetic self-

esteem,fear, dissatisfaction, so from this point of view, appeared to the researcher the idea of this research where the researcher using the method of self-learning multi-level (inclusion) and to identify the extent of its impact on all learning some motor skills and fear of failure and dissatisfaction with the motor impaired students category.

\section{Research objectives:}

1. This research aimsto identify theimpact of the useof self-learningmethod ofmultilevel(Independent variables)

On thevisually impairedpupilsin these Dependent variables:
A. Learn
somemotor skillsinathletics(running,jumping, and throwing).
B. Learn somemotor basketball(shooting,chestpass, scrolloverthehead).
C. Satisfaction of motion.
D. The level of ambition.

\section{Search procedures:}

\section{Research Methodology}

Researcher used the experimental method of measurement of pre and post for the two experimental group one of them experimental and the other governmental. 


\section{Research community}

Tested research impaired students class community of visually school (Taha Hussein for the visually impaired), NasrCity, east of management education.

\section{Sample Search:}

The researcher selected sample in the manner the process of the students of middle prep school (grade I and II ) The volume of the sample (19) students, and were divided into (7) students of the group Pilot,(7) students of the control group, and reached the group reconnaissance (5) students.

\section{Tools used in the research:}

Scientific transactions for Tests and standards

(Motor skills tests- Measure of satisfaction motor -Measure of Ambition Level)

\section{Reliability:}

The researcher conduct scientific tests of transactions in the period from 19/02/2010: $26 / 2 / 2010$, on the exploratory and the sample's (5) pupils from the research community, the significance level ranged between (0.001 to 0.021), levels less than 0.05 level of significance, which the researcher was accepted in condition for the acceptance of differences, therefore, significant differences were accepted for dimensional measurement.

\section{Stability:}

The researcher conducted reliability coefficient, and used the method of application and reapplication and the correlation coefficient ranged between (0.88: 0.95), indicating the stability of the tests under discussion.

\section{The first exploratory experiment:}

The researcher experience exploratory 01/12/2009 and for the following reasons: - View the program on the experts to express their opinion the modification or addition.

\section{Second exploratory experiment:}

Exploratory experiment was conducted in the period between 19/02/2010: 02/26/2010 and for the following reasons:

- Identify problems that may face the researcher during the application and try to solve these problems.

- Make scientific transactions for tests.

\section{Measurement tribal:}

The researcher to conduct measurements in the tribal research variables to calculate the extent of equality of the two groups and that in the period between 28/02/2010: 29/02/2010 and Table (11.10) shows that.

The educational program proposed using the method of self-learning multi-level (include):

\section{Target of the program:}

The preparation of the proposed program for the development of some motor skills to the prep school contest to be in each of athletics and basketball and a self-mobility goal of the program is to provide opportunities for success and self-confidence not to be afraid of failure and the development of independence and selfreliance. To develop a sense of satisfaction motor the researcher has the application of selflearning method of multi-level on the experimental group in the main part of the lesson was done the following steps:

\section{Steps of the program:}

The researcher hanged the board next to each student that contains the panel on the working paper and paper standard was larger writing font size (40) and the illustration, and some large images that contain(Steps gradient skill, levels of required performance, the number of iterations).

-Warm-upfor allmembers ofthe body.

-The researcherpresenteda model ofskill with theexplanation.

-The researcher read the workpaperandexplain how performance.

- Each studentgoes to theboardassigned to him. 
- Each student reads the painting and sees the pictures and chooses the level that suits him according to his abilities.

The performance of each student, if he succeeded in the first level is to move to the next level for the completion of all levels to reach the highest possible level of his abilities.

- If the researcher notices an error in the performance one of the students she should go to him to explain the error by helping in the working paper to read the instructions well.

The researcher divided the units as follows:

\section{3 units of some of the skills of athletics}

- Unit to teach a skill long jump

- Unit to teach the skill to run.

- Unit to teacha skillshot put.

\section{3 unitsof some ofthe skills ofbasketball}

- Unitforthe education ofchestpass.

-Unitfor the educationof thescrollabove the head

-Unitfor the education ofthe shout.

\section{The suitable modification for this research:}

The researcher used part of the society science programs, the measure of Manwetny, lakkson(spss)

\section{View anddiscuss the results:}

Presentation of the results of the
experimental group

The research of the experimental group

Table (1)

Significant differences between tribal and dimensional measurements of the variables in the experimental group search using the test and Walkkson barometry

\begin{tabular}{|c|c|c|c|c|c|c|c|}
\hline Tests & $\begin{array}{c}\text { Transaction Statistics } \\
\text { Variables }\end{array}$ & $\begin{array}{l}\text { Direction } \\
\text { of } \\
\text { reference }\end{array}$ & $\begin{array}{c}\text { The } \\
\text { number } \\
\text { of ranks }\end{array}$ & $\begin{array}{c}\text { The } \\
\text { average } \\
\text { of ranks }\end{array}$ & $\begin{array}{c}\text { Total } \\
\text { of } \\
\text { ranks }\end{array}$ & $\mathrm{Z}$ value & $\begin{array}{c}\text { Level indicative } \\
\text { P }\end{array}$ \\
\hline \multirow{3}{*}{$\begin{array}{l}\text { Motor } \\
\text { skills in } \\
\text { athletics }\end{array}$} & running & $\begin{array}{l}- \\
+\end{array}$ & $\begin{array}{l}1.00 \\
6.00\end{array}$ & $\begin{array}{l}2.00 \\
3.50\end{array}$ & $\begin{array}{c}2.00 \\
19.00\end{array}$ & $-2.76^{*}$ & 0.001 \\
\hline & Long Jumping & $\begin{array}{l}- \\
+\end{array}$ & $\begin{array}{l}1.00 \\
6.00\end{array}$ & $\begin{array}{l}1.00 \\
1.50\end{array}$ & $\begin{array}{l}1.00 \\
9.00\end{array}$ & $-2.62 *$ & 0.003 \\
\hline & throwing & + & $\begin{array}{l}1.00 \\
6.00\end{array}$ & $\begin{array}{l}1.00 \\
2.50\end{array}$ & $\begin{array}{c}1.00 \\
15.00\end{array}$ & $-2.88 *$ & 0.001 \\
\hline \multirow{3}{*}{$\begin{array}{c}\text { Motor } \\
\text { skills in } \\
\text { Basketball }\end{array}$} & Chest pass & $\begin{array}{l}- \\
+\end{array}$ & $\begin{array}{l}1.00 \\
6.00\end{array}$ & $\begin{array}{l}3.00 \\
5.00\end{array}$ & $\begin{array}{c}3.00 \\
30.00\end{array}$ & $-2.75^{*}$ & 0.001 \\
\hline & $\begin{array}{l}\text { the scroll above the } \\
\text { head }\end{array}$ & $\begin{array}{l}- \\
+ \\
\end{array}$ & $\begin{array}{l}1.00 \\
6.00 \\
\end{array}$ & $\begin{array}{l}1.00 \\
4.00 \\
\end{array}$ & $\begin{array}{c}1.00 \\
24.00 \\
\end{array}$ & $-2.82 *$ & 0.007 \\
\hline & shouting & $\begin{array}{l}- \\
+\end{array}$ & $\begin{array}{l}1.00 \\
6.00\end{array}$ & $\begin{array}{l}1.00 \\
3.50\end{array}$ & $\begin{array}{c}1.00 \\
19.50\end{array}$ & $-2.84 *$ & 0.011 \\
\hline \multicolumn{2}{|c|}{ Measure of satisfaction motor } & $\begin{array}{l}- \\
+\end{array}$ & $\begin{array}{l}1.00 \\
6.00 \\
\end{array}$ & $\begin{array}{l}1.00 \\
4.00 \\
\end{array}$ & $\begin{array}{c}1.00 \\
24.00\end{array}$ & $-2.72 *$ & 0.007 \\
\hline \multicolumn{2}{|c|}{ Measure of Ambition Level } & $\begin{array}{l}- \\
+\end{array}$ & $\begin{array}{l}1.00 \\
6.00\end{array}$ & $\begin{array}{l}2.00 \\
3.00\end{array}$ & $\begin{array}{c}2.00 \\
18.00\end{array}$ & $-2.69 *$ & 0.001 \\
\hline
\end{tabular}

Table (1) there are significant differences between the measurements of tribal and post the experimental group in tests of motor skills in athletics, basketball and satisfaction of motor and the level of ambition, It has ranged from the level of significance between (0.001 to 0.011 ) is lower levels of significance level 0.05 , which satisfied the researcher in condition of the acceptance of differences, therefore, significant differences were accepted for dimensional measurement.

\section{Discuss the results of the experimental group}

It's clear from Table (1) the differences between tribal and dimensional measurement for dimensional measurement in the experimental group students in each of the tests of skill and 
scale of satisfaction motor and test the level of ambition.

These results are agreed with what was noted by Kamal Salim special programs kinetic that offers for the visually impaired contribute to the development satisfied of motor and selfconfidence and develop independence and selfhelp on the synergy motor and is also consistent with Alqeraiti, it can give the visually impaired educational experience by teaching methods that rely on the board and large images and clear details that can be hanged on the walls. They are also agreed with what he referred to able to be the development of motor skills for the visually impaired through the development of satisfaction and self-confidence and overcome the disability they have.

Both of Zuhairi and Al-qraiti refer to the visually impaired in need to modern methods of teaching to fit depending on the level of disability they have and their abilities, So the program of teaching the visually impaired must aims to benefit from the remainder of their vision to reduce the pressure of a sense of disability and the development of selfconfidence and provide them with expertise knowledge and the development of independence and out of isolation and complacency and try to reach the level of their peers using the special education schools and

special means suit the degree of disability. (1), (9)

Jaycee M. Harrison explains that the including method helps to increase the ability to deliver according to the level of each student (8).
According to Jaber Abdel-Hamid that the modern methods that rely on raising the student, and motivation that rely on positive student and make it active in the access to expertise to help raise the level to the highest degree of perfection(3).

AlSayehsees that the method of inclusion helps to create a state of satisfaction and reduces anxiety and increases the level of success and progress. (10)

Consistent with the study of Yasmin Mohamed that the programs help develop motor skills, satisfaction with the kinetic class of visually impaired.(11)

It agrees with the toxicity of Somaia Abd Al Hakim that the method of modulated (multilevel) helps to teach motor skills for students in middle school.(12)

Osthuzone \& Gresel also agrees with the study that the method of inclusion (multiple levels) helps to improve physical and skills performance. (13)

Mohamed Saad Zaghloul and Mustafa Al-Sayeh refer to the use of modern methods of teaching which helps the learner to manage the educational situation successfully and to instill behaviors and attitudes of students, therefore, seeks workers in the field of curriculum and teaching methods to arrive at strategies and methods and modern methods to achieve these goals.(6), (10), (14)

\section{Show the results of the control group}

Tribal differences between

the measurements and dimensional variables in the research for the control group 
Table (2)

Significant differences between tribal and dimensional measurements of the variables in the Control group search using the test and Walkkson barometry

\begin{tabular}{|c|c|c|c|c|c|c|c|}
\hline Tests & $\begin{array}{c}\text { Transaction Statistics } \\
\text { Variables }\end{array}$ & $\begin{array}{l}\text { Direction } \\
\text { of } \\
\text { reference }\end{array}$ & $\begin{array}{c}\text { The } \\
\text { number } \\
\text { of ranks }\end{array}$ & $\begin{array}{c}\text { The } \\
\text { average } \\
\text { of ranks }\end{array}$ & $\begin{array}{c}\text { Total } \\
\text { of } \\
\text { ranks }\end{array}$ & $\mathrm{Z}$ value & $\begin{array}{c}\text { Level } \\
\text { indicative } \\
\mathrm{P}\end{array}$ \\
\hline \multirow{3}{*}{$\begin{array}{l}\text { Motor } \\
\text { skills in } \\
\text { athletics }\end{array}$} & running & $\begin{array}{l}- \\
+\end{array}$ & $\begin{array}{l}3.00 \\
4.00\end{array}$ & $\begin{array}{l}4.00 \\
3.50\end{array}$ & $\begin{array}{l}12.00 \\
14.00\end{array}$ & $-1.23 *$ & 0.0124 \\
\hline & Long Jumping & $\begin{array}{l}- \\
+\end{array}$ & $\begin{array}{c}2.0 \\
5.00\end{array}$ & $\begin{array}{l}1.50 \\
2.25\end{array}$ & $\begin{array}{c}3.00 \\
11.25\end{array}$ & $-2.56^{*}$ & 0.005 \\
\hline & throwing & + & $\begin{array}{c}2.0 \\
5.00\end{array}$ & $\begin{array}{l}2.00 \\
3.50\end{array}$ & $\begin{array}{c}4.00 \\
17.50\end{array}$ & $-2.73 *$ & 0.001 \\
\hline \multirow{3}{*}{$\begin{array}{c}\text { Motor } \\
\text { skills in } \\
\text { basketball }\end{array}$} & Chest pass & $\begin{array}{l}- \\
+\end{array}$ & $\begin{array}{c}2.0 \\
5.00\end{array}$ & $\begin{array}{l}2.00 \\
4.00\end{array}$ & $\begin{array}{c}4.00 \\
20.00\end{array}$ & $-2.80^{*}$ & 0.005 \\
\hline & the scroll above the head & $\begin{array}{l}- \\
+\end{array}$ & $\begin{array}{c}2.0 \\
5.00\end{array}$ & $\begin{array}{l}1.00 \\
3.00 \\
\end{array}$ & $\begin{array}{c}2.00 \\
15.00\end{array}$ & $-2.82 *$ & 0.012 \\
\hline & shouting & $\begin{array}{l}- \\
+\end{array}$ & $\begin{array}{c}2.0 \\
5.00\end{array}$ & $\begin{array}{l}3.00 \\
3.00\end{array}$ & $\begin{array}{c}6.00 \\
15.50\end{array}$ & $-2.49 *$ & 0.011 \\
\hline \multicolumn{2}{|c|}{ Measure of satisfaction motor } & $\begin{array}{l}- \\
+\end{array}$ & $\begin{array}{l}3.00 \\
4.00\end{array}$ & $\begin{array}{l}5.00 \\
4.00\end{array}$ & $\begin{array}{l}15.00 \\
16.00\end{array}$ & $-1.51^{*}$ & 0.117 \\
\hline \multicolumn{2}{|c|}{ Measure of Ambition Level } & $\begin{array}{l}- \\
+\end{array}$ & $\begin{array}{c}2.0 \\
5.00\end{array}$ & $\begin{array}{l}2.00 \\
3.00\end{array}$ & $\begin{array}{c}4.00 \\
15.00\end{array}$ & $-2.34 *$ & 0.012 \\
\hline
\end{tabular}

there are significant differences between the measurements of tribal and post the group control in tests of motor skills in athletics, basketball and satisfaction of motor and the level of ambition, has ranged from the level of significance between (0.001 to 0.012), levels below the level of significance of 0.05 , which the researcher is satisfied in one condition for the acceptance of differences, therefore, significant differences were accepted for dimensional measurement, except a test running, or the shouting

at the levels of significance greater than 0.05 .

\section{Discuss the results of the control group}

From the table (2)it is clear the differences between tribal and dimensional measurement for dimensional measurement in the control group students ineach of the skills tests and a measure of satisfaction motor and test the level of ambition.

These results are agreed with what was noted by Kamal Salim programs that provide mobility for the visually impaired, contribute to the satisfaction development of motor and selfconfidence and develop independence and selfhelp to motor synergies.

It agrees with the study of Yasmin Mohamed that the programs of motor skills help to develop,motor and satisfaction with the kinetic class of visually impaired. (11)

And also agrees with the study of Osthuzone \& Gresel that the method of inclusion (multiple levels) helps to improve physical performance and skills. (13)

\section{Show the differences between the two groupsBottom of Form}


Table (3)

Significant differences between the two sets of measurements dimensional experimental and the control variables in the research Using the Mann Whitney test barometry

\begin{tabular}{|c|c|c|c|c|c|c|c|}
\hline Tests & $\begin{array}{c}\text { Transaction Statistics } \\
\text { Variables }\end{array}$ & The group & $\begin{array}{c}\text { The } \\
\text { number } \\
\text { of ranks }\end{array}$ & $\begin{array}{c}\text { The } \\
\text { average } \\
\text { of ranks }\end{array}$ & $\begin{array}{c}\text { Total } \\
\text { of } \\
\text { ranks }\end{array}$ & $\mathrm{U}$ value & $\begin{array}{c}\text { Level } \\
\text { indicative } \\
\mathrm{P}\end{array}$ \\
\hline \multirow{3}{*}{$\begin{array}{l}\text { Motor } \\
\text { skills in } \\
\text { athletics }\end{array}$} & running & $\begin{array}{c}\text { Control } \\
\text { experimental }\end{array}$ & $\begin{array}{l}1.00 \\
6.00\end{array}$ & $\begin{array}{l}2.50 \\
4.00\end{array}$ & $\begin{array}{c}2.50 \\
24.00\end{array}$ & $-2.68 *$ & 0.004 \\
\hline & Long Jumping & $\begin{array}{c}\text { Control } \\
\text { experimental }\end{array}$ & $\begin{array}{l}1.00 \\
6.00\end{array}$ & $\begin{array}{l}1.00 \\
3.00\end{array}$ & $\begin{array}{c}1.00 \\
18.00 \\
\end{array}$ & $-2.49 *$ & 0.004 \\
\hline & throwing & $\begin{array}{c}\text { Control } \\
\text { experimental }\end{array}$ & $\begin{array}{l}1.00 \\
6.00\end{array}$ & $\begin{array}{l}3.00 \\
4.25\end{array}$ & $\begin{array}{c}3.00 \\
25.50\end{array}$ & $-2.68 *$ & 0.001 \\
\hline \multirow{3}{*}{$\begin{array}{c}\text { Motor } \\
\text { skills in } \\
\text { basketball }\end{array}$} & Chest pass & $\begin{array}{c}\text { Control } \\
\text { experimental }\end{array}$ & $\begin{array}{l}1.00 \\
6.00\end{array}$ & $\begin{array}{l}3.50 \\
5.00\end{array}$ & $\begin{array}{c}3.50 \\
30.00\end{array}$ & $-2.81 *$ & 0.001 \\
\hline & the scroll above the head & $\begin{array}{c}\text { Control } \\
\text { experimental }\end{array}$ & $\begin{array}{l}1.00 \\
6.00\end{array}$ & $\begin{array}{l}2.50 \\
3.25\end{array}$ & $\begin{array}{c}2.50 \\
19.50\end{array}$ & $-2.64 *$ & 0.002 \\
\hline & shouting & $\begin{array}{c}\text { Control } \\
\text { experimental }\end{array}$ & $\begin{array}{l}1.00 \\
6.00\end{array}$ & $\begin{array}{l}3.25 \\
4.50\end{array}$ & $\begin{array}{c}3.25 \\
27.00\end{array}$ & $-2.69 *$ & 0.001 \\
\hline \multicolumn{2}{|c|}{ Measure of satisfaction motor } & $\begin{array}{c}\text { Control } \\
\text { experimental }\end{array}$ & $\begin{array}{l}1.00 \\
6.00\end{array}$ & $\begin{array}{l}4.00 \\
4.50\end{array}$ & $\begin{array}{c}4.00 \\
27.00\end{array}$ & $-2.88 *$ & 0.014 \\
\hline \multicolumn{2}{|c|}{ Measure of Ambition Level } & $\begin{array}{c}\text { Control } \\
\text { experimental }\end{array}$ & $\begin{array}{l}1.00 \\
6.00\end{array}$ & $\begin{array}{l}2.00 \\
3.50\end{array}$ & $\begin{array}{c}2.00 \\
21.00\end{array}$ & $-2.71^{*}$ & 0.001 \\
\hline
\end{tabular}

There are significant differences between the measurements dimensional for the two experimental and control group in tests of motor skills in athletics, basketball and satisfaction of motor and the level of ambition in favor of the experimental group, and ranged from the level of significance between (0.001 to 0.014$)$, levels greater than the significance level 0.05 researcher who satisfied in one condition of the acceptance of differences and therefore has been not to accept significant.

Table (4)

Rates of change between the tribal and dimensional measurements of the two sets of experimental and control variables in the research

\begin{tabular}{|c|c|c|c|c|c|c|c|c|}
\hline Tests & \multirow{2}{*}{ Variables } & \multicolumn{3}{|c|}{ The control group } & \multicolumn{3}{|c|}{ The experimental group } & \multirow{2}{*}{$\begin{array}{c}\text { The } \\
\text { differences }\end{array}$} \\
\hline \multirow{4}{*}{$\begin{array}{l}\text { Motor skills in } \\
\text { athletics }\end{array}$} & & $\%$ & post & Pre & $\%$ & post & pre & \\
\hline & running & 8.88 & 6.57 & 7.21 & 29.17 & 5.10 & 7.20 & 20.69 \\
\hline & Long Jumping & 8.33 & 1.95 & 1.80 & 14.53 & 2.05 & 1.79 & 6.20 \\
\hline & throwing & 9.23 & 7.69 & 7.04 & 27.03 & 8.39 & 7.03 & 17.18 \\
\hline \multirow{3}{*}{$\begin{array}{c}\text { Motor skills in } \\
\text { basketball }\end{array}$} & Chest pass & 8.36 & 18.14 & 16.74 & 27.86 & 21.34 & 16.69 & 19.50 \\
\hline & $\begin{array}{c}\text { the scroll above } \\
\text { the head }\end{array}$ & 10.10 & 17.24 & 15.66 & 24.36 & 19.45 & 15.64 & 14.35 \\
\hline & shouting & 9.15 & 3.10 & 2.84 & 24.21 & 4.13 & 2.86 & 15.06 \\
\hline \multicolumn{2}{|c|}{ Measure of satisfaction motor } & 13.48 & 120.13 & 114.67 & 29.26 & 148.26 & 114.70 & 15.78 \\
\hline \multicolumn{2}{|c|}{ Measure of Ambition Level } & 20.67 & 70.00 & 58.01 & 43.03 & 83.00 & 58.03 & 22.36 \\
\hline
\end{tabular}

Rates of change between the tribal and dimensional measurements of the experimental athletics, basketball, motor satisfaction and and control groups in tests of motor skills in 
Discuss the results of the differences between the experimental group and control group

It's clear from Table $(3,4)$ there are significant differences between the experimental group and control group in the dimensional measurement for the experimental group, and this agrees with the study of:Jasmine Mohamed, AbdelHakim, and the study OShthuzone \& Gresel to the experimental group than the control group on tests of motor skills after using the method of embedding (multiple levels). (11)(12)(13)

These results are also agrees with what was noted by Kamal Salim programs kinetic special offers for the visually impaired contribute to the development consent of motor and selfconfidence and develop independence and selfhelp on the synergy motor and is also agrees with Al-qraiti it can give the visually impaired educational experience by teaching methods that rely on the board, photos, large and clear details that can be suspended on the walls. And are also consistent with what he referred to could be the development of motor skills for the visually impaired through the development of satisfaction and self-confidence and overcome the disability they have. (9)

Indicates that Zuhairi visually impaired in need of modern teaching methods to suit depending on the level of disability they have and their abilities.(1)

Jaycee M. Harrison explains that the inclusion method helps to increase the ability to deliver according to the level of each student.

According to Jaber Abdel-Hamid that the modern methods that rely on raising the student, and payers that rely on positive student and make it active in the access to expertise to help raise the level to the highest degree of perfection.(3)

Al Sayeh sees that the method of inclusion helps to create a state of satisfaction and reduces anxiety and increases the level of success and progress.(10)

And consistent with the toxicity of Somaia Abd Hakim that the method of modulated (multilevel) helps to teach motor skills for students in middle school.(12)

It also agrees with the study Osthuzone \& Gresel that the method of inclusion (multiple levels) helps to improve physical performance and skills.(13)

Indicates Magdy Aziz, Mahmoud Dawood to the methods of teaching advanced and nontraditional care performance diligent to the individual and the development of both selfreliance and skills calendar, Self-help to achieve the goals of the educational process to ensure access learner to the high efficiency and perfection in performance.(15), (16)

\section{Conclusions:}

According to the nature of the research objectives and after the presentation and analysis and discuss the results could be reached to these Conclusions:

1. resulted in the production of the existence of significant differences between tribal and dimensional measurement of the experimental group for dimensional measurement in all variables of the research.

2. Resulted in findings of the existence of significant differences between the experimental group and control group for the experimental group after using the method to include all the variables in the research.

3. Self-learning method of multi-level (modulated) than command method to learn some motor skills and in the category of visually impaired students.

4. Method of self-learning multi-level (modulated) than approach it in the development of motor and satisfaction level of ambition in the category of visually impaired students.

\section{Recommendations:}

1. should be given to the category of visually impaired due to the continuous increase in the number in special education schools.

2. Make many of the research in the field of visual disability as the motor skills of visually impaired children close to a large extent from the normal methods, if available and appropriate ways in education.

3. Diversity in the use of modern teaching methods in teaching classes for the teacher to 
helpachieve the objectives of the educational process.

\section{References:}

1. Al Zuhair, I, Abase, (2007):" Raising the disabled and the gifted and their education systems, international expertise", Dar Alfakr Al Araby, Cairo, pp 253-342(in Arabic)

2. Denial D.Arnheim (1993):" Physical Education for special population development"adapted and remedial approach, united stats.pp56-57.

3. Abdel Hamid, Gaber, (2006): "contemporary trends and experiences in the performance of the student and the teacher", Dar Alfakr Al Araby, Cairo, pp 145(in Arabic)

4. Rashid, Ali (2005):" Successful teacher and basic skills", Dar Alfakr Al Araby, Cairo, pp 25(in Arabic)

5. Abdel Hamid, Gaber, (1991): "strategies for teaching and learning", Dar Alfakr Al Araby Cairo, pp 403(in Arabic)

6. Zaghloul, M, Mustafa (2004):" technology development and rehabilitation of physical education teacher" Dar Al- Wafaa for printing and publishing, Alexandria, pp 125(in Arabic)

7.Salem, Kamal (1996):" visually impaired, their characteristics and methods", Cairo, Egyptian-Al Dar Lebanese, pp 174,175(in Arabic)

8. Jaycee M. Harrison (1996): "Instructional Strategies for Secondary School Physical Education" 4th Ed., Brown Benchmark, pp 127.
9. Abd al-Muttalib Alqraiti (2005):" the psychology of people with special needs and education" Dar AlfakrAl Araby,Cairo, pp403,405(in Arabic)

10. Sayeh,M, Mohammad\&Khafajiy, M, Ali (2004):" Encyclopedia of education"Dar Alfakr Al Araby Cairo,pp 174,175(in Arabic)

11. Mohammad, Y (1997): "the impact of a proposed program for the development of some motor skills on the basic physiological efficiency and satisfaction for the Blind in the motor primary," PhD Faculty of Physical Education for Girls on the island, HelwanUniversity,pp 74 (in Arabic)

12. AbdelHakim, S, Ahmed (2001):" the impact of the multi-level self-learning to learn some skills of gymnastics with the pupils of the second cycle of basic education", unpublished Master, Faculty of Physical Education for Girls, MiniaUniversity, pp 80(in Arabic)

13. Osthuzen, M.\& Geisel, J. (1992):"The effect of the command reciprocal and inclusion teaching style on the realization of objective in physical education for high school boys", S.A. Journal for research, in sport physical education, London,pp 174,175

14. Kojak, K (1999):" A Strategy EducationalStudies" Volume 7, World books, Cairo, pp43, 46 (In Arabic)., pp 76.

15. al-Rubaie, M, Dawood (2006):"ways and methods of teaching contemporary", Amman, Jordan, the modern book world, pp159 (In Arabic).

16. Magdy Aziz Ibrahim (2003): "Encyclopedia of Teaching" Part II, Dar AlMaisra,Cairo, pp 22 (In Arabic). 